\title{
International Journal of Ayurveda and Pharma Research
}

\section{Review Article}

\section{ANCIENT METHODS OF RESEARCH IN AYURVEDA}

\section{Kirti Soni1*, Rohit Ranjan², Vijay Shankar Pandey ${ }^{3}$}

${ }^{*}$ MD Scholar, ${ }^{2}$ Assistant Professor, ${ }^{3}$ Professor and H.O.D, Department of Ayurved Samhita and Siddhanta, Government Ayurvedic College, Patna, India.

\begin{abstract}
Ayurveda is the Upaveda of Atharvaveda, the ancient literature which gave us the knowledge of healthier life. The absolute aim of Ayurveda is to maintain the health of a healthier person and diagnose and treat the diseased person. Ayurveda has the ability to treat many chronic diseases that are untreatable in modern medicine, it has got some very preventive and curative tools to treat the diseases, but unfortunately, due to the lack of scientific validation in various concepts, this precious gift from our ancestors is trailing. In a nutshell, Ayurveda gives human a healthy life with proven methods of medical treatment. The ancient methods of treatment are very effective and relevant in present time also. Hence, evidence-based research is highly needed for global recognition and acceptance of Ayurveda, which needs further advancements in the research methodology.
\end{abstract}

KEYWORDS: Ayurvedic Research methodology.

\section{INTRODUCTION}

Ayurveda is the oldest medical system, which comprises a number of medical concepts and hypothesis. It is a science of life with a holistic approach to health and personalized medicine. It is known to be a complete medical system that comprised physical, psychological, philosophical, ethical, and spiritual health.

We are five thousand years away from the time when Ayurveda was practiced uniquely. The principle of the science then and now is the same; these are to be review in the context of modern lifestyle and the ever-progressive scientific research. The commencement of any Ayurvedic research primarily requires a complete understanding of all the basic principles laid down by the ancient Ayurvedic experts. The major problem faced by an Ayurvedic research worker is the unavailability of a standard protocol for basic research. With the collection of all the scattered references in Ayurvedic classics, we will get the idea of ancient Ayurvedic experts about their mode of research, this will help us in right direction. ${ }^{[1]}$

\section{Definition}

The research word came from French word 'Recherche' which means to go about seeking. The earliest recorded use of the term was in 1577.[2] The word defines as-

- $\quad \mathbf{R e}=$ Often

- $\quad$ Search $=$ To find
In another context to the word also defines as [3]

$\mathrm{R}$ - Rethinking

E - Experimental method

S - Survey

E - Evaluation

A - Age/Attitude/Attitude/

$\mathrm{R}$ - Recognition

C - Current affairs

$\mathrm{H}$ - Head/Heart/Health/Hand

\section{Research [4]}

1. Defined as a Scientific and Systematic search of information on specific topic.

2. Establishing the old facts with the present knowledge.

3. Searching for the existing phenomenon and putting it into scientific and logical (correct and valid reasoning) manner.

4. Verification of old facts and finding out new facts (Invention-is inventing and Revalidation- Giving evidence).

In short, research defined as to investigate, to find, to examine, to discover new facts and verify old ones by scientific approach of a subject.

In Ayurveda, Acharya Priyavrath Sharma defined research as, "The study of cause and effect relationship between Dravya-Guna-Karma after several observations and through verifiable examination, arrival at final conclusion is called as 
Anusandhana." [5] The objective of Anusandhana is to remove the complicity in subject and find the truth.

In Charak Samhita the qualities of researcher are Vidhya, Vitarka, Vigyan, Smirti, Tatparta, Kriya which denotes the knowledge, reasoning, scientific method, memory, preparedness, and practical approach for any research process. ${ }^{[6]}$

\section{Synonyms of Anusandhana [7]}

\begin{tabular}{|l|l|l|}
\hline 1. & Anusandhana & $\begin{array}{l}\text { Anu= to follow, Sandhana= } \\
\text { appropriate knowledge, i.e. To } \\
\text { follow appropriate knowledge. }\end{array}$ \\
\hline 2. & Gaveshana & $\begin{array}{l}\text { To search or to achieve with } \\
\text { the help of all sense. }\end{array}$ \\
\hline 3. & Anveshana & $\begin{array}{l}\text { Anu= continuous, Eshana= } \\
\text { desire, i.e. Desire to search. }\end{array}$ \\
\hline 4. & Paryeshana & $\begin{array}{l}\text { Pari= from all the dimensions, } \\
\text { eshana= to search i.e. To search } \\
\text { from all dimensions. }\end{array}$ \\
\hline
\end{tabular}

Other equivalent terms used for word research [8]

\begin{tabular}{|c|l|l|}
\hline 1. & Investigation & $\begin{array}{l}\text { The work of inquiring into } \\
\text { something thoroughly and } \\
\text { systematically }\end{array}$ \\
\hline 2. & Invention & The act of inventing \\
\hline 3. & Enquiry & A search for knowledge \\
\hline 4. & Exploration & A careful systematic search \\
\hline 5. & Verification & $\begin{array}{l}\text { Additional proof that something } \\
\text { that was believed some fact, } \\
\text { hypothesis or theory) is correct }\end{array}$ \\
\hline 6. & Discovery & $\begin{array}{l}\text { The act of discovering } \\
\text { something }\end{array}$ \\
\hline 7. & Quest & $\begin{array}{l}\text { The act of searching for } \\
\text { something new }\end{array}$ \\
\hline
\end{tabular}

\section{DISCUSSION}

In ancient time, there were the classical techniques of research and investigation in Ayurvedic science, which includes:

1. Paryeshana (Observations) and Pariksha (Experiments)

2. Chaturvidha Pramana (Means of investigations)

a) Pratyaksha (Perception)

b) Anumana (Inference)

c) Aptopadesha (Authoritative testimony)

d) Yukti (Reasoning or Experiment)

3. Prashna and Sambhasha

4. Some other methods for the validity of Observations and Experiments are - Avastha

5. Panchaavayava

6. Samkhya (Figures)

7. Research tools - Tantrayukti, Tantra.

\section{Pratisanskar}

\section{Observation and Experiment (Paryeshana and Pariksha) ${ }^{[9]}$}

The term observation denotes the ability to notice things carefully. It is the active acquisition of information from a primary source. In the field of Anusandhana, the term Paryeshana states- Study should be done by observing/analyzing the subject from all dimensions. In Ayurveda, at some points like comparison of nature's elements with human body and elements for their similarity, needs and intensive study of literature as well as nature, which is performed in two ways- Microscopic study and Macroscopic study. To understand the basics of body elements, Dosha, Dhatu, Mala etc microscopic study plays an important role.

Ayurvedic Siddhantas also plays an important role in these studies as they provide a clear and deep knowledge about human health, body elements, nature, science etc. Starting from basics, the basic root (Mula) of body is Tridosha that is Vata, Pitta, Kapha. These Tridosha, provides nourishment to body in their natural state where as in vitiated state they are the cause of diseases. The study of Tridosha theory and their management in various conditions, observational study plays an important role.

The Observation study of Ayurvedic Siddhantas is very helpful in gaining knowledge of hidden meanings of the quotations (Shlokas) stated by Acharyas.

Study of Prati Purush Siddhanta[10] shows a great approach towards research as it says every individual is different which creates a chance for experimenting different kinds of medicines and observe its effect on every individual.

Study of Loka Purush Samya Siddhanta[11] shows that how an individual is an epitome of the universe all the material and spiritual phenomena of the Universe are present in an individual and all those Bhava present in the individual are also contained in Universe.

\section{Pramanas}

Ayurveda has its own principles and concepts. To acquire the knowledge of these concepts and principles Pramanas are essential. As Ayurveda is an independent and unique science of medicine, it has some independent Pramanas also. The physiological activities of various body parts and body organs, and the action of Aushadha and Aaharadravya on the body are comprehended through Pramanas only.

In the Indian literature, Pramanas lead an important role in acquiring complete and valid knowledge about evolution, dissolution, soul, 
primordial nature, heaven, hell, liberation etc. Pramanas are the means or instruments which play an important role in acquiring proper knowledge. Pramanas are the base for getting the valid or real knowledge of matter, and for the standardization of the objects. ${ }^{[12]}$

With the help of these Pramanas the cause and symptoms of the diseases, the diagnosis of diseases and line of treatment can be understood which is very beneficial in research methodology.[13]

The examination and correct knowledge of the disease, patient, substance, quality and action etc. is to be confirmed on the base of Pramanas.

According to the Nyaya Deepika- "The valid knowledge is called Pramana."

In Ayurveda, Acharya Charak described the three types of Examinations (Pramanas) for acquiring the significant knowledge of the diseases.[14] Whereas, while proving the existence (Sat padarth) or non-existence (Asat padarth) Acharya Charak described the four types of examinations (Pramanas).[15]

\section{Synonyms of Pramana or Pariksha:[16]}

Gangadhar, the famous commentator of Charak Samhita stated the following synonyms for Pramanas are:
1. Upalabdhi (Attainment)
2. Sadhan (Means/Source)
3. Gyan (Knowledge)
4. Pariksha (Investigation)
5. Pramana (Examinations)

\section{Importance of Pramana}

The main purpose of Ayurveda is to maintain the normalcy of the Dosha in healthy persons and to treat the patients ailing with the diseases. For the fulfillment of this aim, valid and proper knowledge is essential, which arises through the means called as Pramanas.

\section{a) Pratyaksha Pramana (Direct Perception)}

Though Ayurveda accepts various types of methods of the knowledge, the superiority of Pratyaksha remains unchallenged.

Pratyaksha Pramana plays a prominent role among all other Pramanas.

The term Pratyaksha is derived from two words - 'Prati+ Aksha' which means in front of the eyes. In the context of $A k s h a$, it should be understood that, the knowledge occurs not only through Eyes/ Chakshurendriya but from the all five Gyanendriya.
While describing the characteristic feature of Pratyaksha (perception) Acharya Charak stated that, Perception of the Bhavas like Sukh (happiness), Dukh (misery), Iccha (desire), Dwesha (hatred) and the knowledge of the objects get through the Indriyas (sense organs) which are Shabda (sound), Sparsha (touch), Roop (colour), Rasa (taste), Gandha (smell) is called as Pratyaksha.[17]

Acharya defined Pratyaksha as, it is the instantaneous knowledge manifested by the conjugation of the soul (Atma), the sense organs (Indriyas), the mind (Mana) and the Indriyarthas. ${ }^{[18]}$

By observing the above statement, it is understood that forgetting knowledge through Perception; Conjugation of Atma (soul) and Mana (Mind) is essential.

\section{Atma}

According to Tarka Sangrah, Atma (the soul) is the seat of knowledge. Whereas, the statement of Acharya Charak is more precise regarding Atma- The Empirical soul (Atma) is endowed with the power of perception when conjugates with Gyanendriya. [19]

\section{Indriyas and Indriyarthas}

Indriyas are very important organs in human body, they are mostly related to soul (Atma) and helps the soul to get the knowledge of the objects.[20] According to Acharya Charaka, Indriyas are the basic components or instruments in differentiating the living and non-living matters.[21] Whereas, in Indriyasthanam Acharya Charak stated that the sign and symptoms of life are called Indriyas.

According to Acharya Sushruta, Indriyas are the specific factors or organs situated in the body which acts as the means for acquiring the knowledge of various objects and performing various activities of body.[22] Generally, there are eleven Indriyas- Five Gyanendriyas, five Karmendriyas, one Ubhayendriya (Mana).

Acharya Sushruta accepted the development of these sense organs from five Mahabhutas (Akash, Vayu, Agni, Jala, Prithvi).

Acharya Charak gave the concept of Pancha Panchak ${ }^{[23]}$ in which each Indriya has relation with its corresponding organs (Adhishthanas), objects (Indriyarthas), elements (Indriya dravyas), and perceptions (Indriya buddhi), which totally contains twenty-five objects. All Pancha Panchak are related to Pratyaksha Pramana. Hence, they lead an important role in it. As shown in the table below.[24] 


\begin{tabular}{|c|c|c|c|c|c|}
\hline $\begin{array}{c}\text { Panchendriya } \\
\text { (Five Sense } \\
\text { Faculties) }\end{array}$ & $\begin{array}{c}\text { Panchendriya } \\
\text { Dravya } \\
\text { (Five Sense } \\
\text { Elements) }\end{array}$ & $\begin{array}{c}\text { Panchendriya } \\
\text { Adhishthana } \\
\text { (Five Sense } \\
\text { Organs) }\end{array}$ & $\begin{array}{c}\text { Panchendriya } \\
\text { Artha } \\
\text { (Five Sense } \\
\text { Objects) }\end{array}$ & $\begin{array}{c}\text { Panchendriya } \\
\text { Buddhi } \\
\text { (Five Sense } \\
\text { Perceptions) }\end{array}$ & $\begin{array}{l}\text { Use of Pratyaksha } \\
\text { Pramana as clinical } \\
\text { methodology }\end{array}$ \\
\hline Srotrendriya & Akash & Karna & Shabda & $\begin{array}{c}\text { Srotraja } \\
\text { Buddhi }\end{array}$ & $\begin{array}{l}\text { Gurgling sound in the } \\
\text { intestines, cracking } \\
\text { sound in the joints, } \\
\text { hoarse voice of patient, } \\
\text { sound of cough, sneeze, } \\
\text { hiccups, sounds of } \\
\text { lungs, heart and other } \\
\text { organs filled with } \\
\text { froth/blood. }\end{array}$ \\
\hline Sparshanendriya & Vayu & Twak & Sparsha & $\begin{array}{c}\text { Sparshna } \\
\text { Buddhi }\end{array}$ & $\begin{array}{l}\text { The normal and } \\
\text { abnormal touch of the } \\
\text { patient can be } \\
\text { examined by hand. By } \\
\text { Sparshna, examination } \\
\text { of body temperature of } \\
\text { a patient can be done. } \\
\text { Oedema/pitting } \\
\text { oedema, smooth or } \\
\text { rough skin can be } \\
\text { examined. }\end{array}$ \\
\hline Chakshurendriya & Agni & Akshi & $P$ & $\begin{array}{c}\text { Chakshur } \\
\text { Buddhi }\end{array}$ & $\begin{array}{l}\text { The knowledge of } \\
\text { natural colours like } \\
\text { white, black etc. and } \\
\text { unnatural colours like } \\
\text { blue, grey etc. } \\
\text { Height, weight, age of } \\
\text { patient; strength and } \\
\text { development of body; } \\
\text { change in colour of } \\
\text { wound, inflammation } \\
\text { area etc. can be } \\
\text { examined. }\end{array}$ \\
\hline Rasanendriya & Jala & Jihwa & Rasa & $\begin{array}{l}\text { Rasana } \\
\text { Buddhi }\end{array}$ & $\begin{array}{l}\text { This can be known by } \\
\text { interrogating the } \\
\text { patient or by Anumana } \\
\text { Pramana. Tastelessness } \\
\text { of mouth in Jwara. } \\
\text { Sweetness of mutra } \\
\text { (urine) in Prameha as } \\
\text { ants are attracted } \\
\text { towards it. } \\
\text { Purity of blood if crows } \\
\text { and dogs eat it. }\end{array}$ \\
\hline Ghranendriya & Prithvi & Nasa & Gandha & $\begin{array}{c}\text { Ghranaja } \\
\text { Buddhi }\end{array}$ & $\begin{array}{l}\text { Normal and abnormal } \\
\text { smell of patient's body. } \\
\text { Arishta Lakshana can } \\
\text { also be examined. } \\
\text { Various smells of Vrana } \\
\text { srava in various stages. } \\
\text { Urinary smell of } \\
\text { (Lohagandha) } \\
\text { septicaemia. } \\
\text { Putigandha while taking }\end{array}$ \\
\hline
\end{tabular}




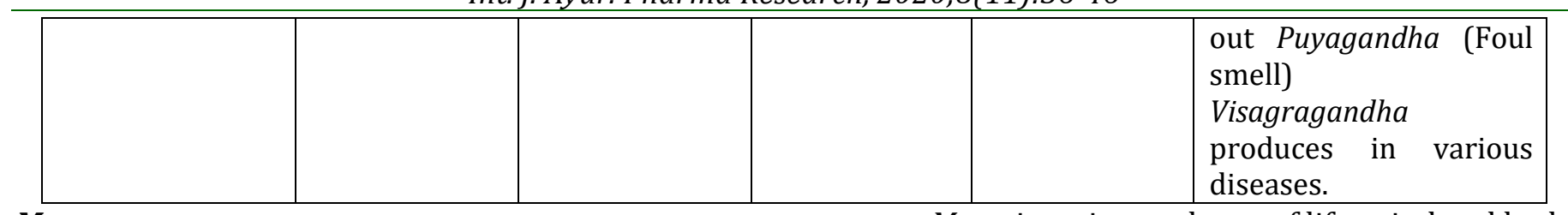

\section{Mana}

Human being has a significant place among the Sendriya dravyas of the universe. Though Mana (mind) is existed in all the sentient beings, it has more important role and utility in human beings. If the mind in healthy and stable an individual will be able to perform his duties normally, but if the mind (Mana) is affected, all the activities of all the organs will be obstructed.

The word Mana or Manas is derived from the Dhatu-Man gynae, which expresses knowledge. So here, the Mind (Mana) plays an important role in perceiving the knowledge but not independently. When it associates with Atma (soul) and Indriyas (sense organs) then only it perceives the knowledge. [25]

In absence of one of the above two, perception will not happen.

Acharya Charak describes the characteristics of Mana as the occurrence and non-occurrence of cognition are the character of Mana. If the Mind (Mana) contacts with the Soul (Atma), the sense organs (Indriyas) and their objects (Indriyarthas) then only, cognition will occur otherwise in the absence of the contact cognition does not occur.[26]

Acharya says that the mind (Mana) motivates the sense organs (Indriyas) to perceive the knowledge of their respective objects.[27]

Mana has the enormous power of control over the body, that's why it has got a specific place in treatment. Mana has been accepted as a seat of diseases like body.

As already discussed, for ideal health the equilibrium stages of Dosha, Dhatu, Mala, Kriya, and Agni along with the happiness of soul, senses and mind is essential.[28]
Mana is an integral part of life, mind and body cannot be separated. The factor affecting mind will affect the body too. For example, consumption of spicy foods vitiates 'Pitta dosha', which is a physical factor. Similarly, Anger which is a mental factor, equally responsible for aggravation of Pitta dosha. [29]

On the other hand, the material (Dravya) containing sweet taste increases 'Shleshma dosha' in the body, and also increases sleepiness and lethargy etc. which are known to be mental factors.

So as far as pathogenic factors of mind are concerned, they can be reconciled only by taking recourse to spiritual and scriptural knowledge, patience, memory and meditation. ${ }^{[30]}$ So, the proper utilization of mental faculty is beneficial to the maintenance of normal health. ${ }^{[31]}$

Thus, it is established fact that the mind (Mana) has got very important role in the medical science and an efficient physician requires a good knowledge of Psychology.

\section{Anumana Pramana (inference)}

All the systems of Indian philosophy hold Anumana as a distinct means of knowledge. The term 'Anumana' consists of two words Anu = after + maana = knowledge/cognition. Thus, Anumana is the knowledge which comes after perception. ${ }^{[32]}$

According to Tarka Sangrah, Anumana (Inference) is the act of knowing something unknown from the known data. ${ }^{[33]}$ According to Acharya Charak the inference is based on argument accompanied by reasoning. [34]

Acharya Charak gave another statement for Anumana Pramana which clarifies its utility in clinical methodology. According to Acharya, the Inference (Anumana) is antecedent by perception (Pratyaksha). It gives the knowledge of past, present and future ${ }^{[35]}$ as shown in table below: ${ }^{[36,37]}$

\begin{tabular}{|l|l|}
\hline $\begin{array}{l}\text { Past } \\
\text { (Seshavadanumana) }\end{array}$ & $\begin{array}{l}\text { This says cause always exists before any effect, as by saying the pregnancy, the } \\
\text { act of sexual intercourse performed in the previous period is inferred. } \\
\text { This inference helps us to understand that if a patient comes to us with a } \\
\text { complaint of particular disease it is understood that the Nidana sevana in } \\
\text { previous period has occurred. }\end{array}$ \\
\hline $\begin{array}{l}\text { Present } \\
\text { (Samanyata } \\
\text { drishtanumana) }\end{array}$ & $\begin{array}{l}\text { The inference based on the mark of sign is described in this method. As the } \\
\text { inference of fire by seeing smoke can be understood. }\end{array}$ \\
\hline $\begin{array}{l}\text { Future } \\
\text { (Purvadanuman) }\end{array}$ & $\begin{array}{l}\text { This defines where reason is estimated from the work done. This is also called } \\
\text { as Karanat karyanumana e.g. by seeing the seed the forthcoming fruit is } \\
\text { inferred. The forthcoming rain inferred by seeing the clouds. }\end{array}$ \\
\hline
\end{tabular}


Kirti Soni, Rohit Ranjan, Vijay Shankar Pandey. Ancient Methods of Research In Ayurveda

As it is stated that the factors in the body which are perceived through Anumana Pramana in more in number than that of Pratyaksha Pramana.

Despite of such an important method of clinical examination i.e. perception; sometimes we have to take the help of logical inferences.

Anumana Pramana helps to understand the relation to physiology or pathology of body functions. For an instance, in a patient of arthritis to access the overall improvement after treatment, one has to interrogate them about while walking they need a support or not, is there any painful occurs while walking etc. we can predict through Anumana Pramana that anti-arthritic drug is acting well in patient. According Acharya Charak there are lots of conditions of body (Physiological and Pathological) in which inference exam is important.[38]

\section{Aptopadesha Pramana (Authoritative Testimony)}

Though all other Darshanas gave first preference to Pratyaksha Pramana, Ayurveda has given first place to Aptopadesha Pramana. [39]

Ayurveda says Aptopadesha is base of all Pramanas as it plays an important role to acquire the existing knowledge which helps research scholars in further research works/experiments. All the previous research scholars, or authority people who had spent their valuable time for acquiring knowledge; compiled and wrote down their experiences and research works texts.[40] These texts help a research scholar to examine the facts and parameters, to be applied for verification. According to Acharya Charaka, the authoritative instructions trustworthy (Apta) are known as Aptopadesha. These persons are free from attachment and grief, they are impartial and dedicated to the pursuit of truth and knowledge. [41] Describing the Apta (authoritative persons), Acharya Charak emphasizes, those enlightened and refined persons who are absolutely free from the predominance of Rajas and Tamas (Mansika dosha) by virtue of the power of penance and knowledge and who are always in possession of an uninterrupted knowledge pertaining to past, present and future are known as Aptas, Shista (gentlemen) and Vibuddha (enlighted persons). Their words are true and beyond any doubt.[42,43] In Ayurveda, there are so many factors where the direct perception or inference is not useful, the matter can be ascertained by testimony only.

In Ayurveda, Aptopadesha plays a very important role in development of scientific knowledge. According to Acharya Charaka, one can know of a disease from the authoritative statement first and then he should confirm its various characteristics by examining the symptoms of diseases through the perception and inference.
The different aspects of examination through Aptopadesha. ${ }^{[44]}$

- The aggravating factors of diseases e.g.: Snigdha dravyas etc.

- Involvement of source of Doshas.

- Mode of manifestation of the diseases.

- Nature of diseases- whether its acute or chronic, serious or not.

For e.g.: Acuteness of syncope, seriousness of diphtheria.

- Location of organs of the body and mind etc.

- Pain

- Symptoms

- Complications

- Association with specific sounds, touch, colours, tastes and smell.

- Association with aggravation, neutrality and decreasing.

- Prognosis, Names, Accompanying factors.

- Prescription and prohibitions in the treatment.

The knowledge of the above factors can be attained through Aptopadesha (Authoritative Testimony) has proven its supremacy in the field of medicine.

\section{Yukti Pramana (Reasoning or Examination)}

Ayurveda, particularly Acharya Charak only accepted Yukti (Reasoning) as a Pramana. The word Yukti denotes- union, junction, combination, application, practice an expedient a plan or a scheme, reasoning, arguing, arrangement etc.[45] Acharya Charak has used the term in a wide reference and has described that the author which perceives thing as outcomes of combination of causative factors valid for Past, Present and future is known as Yukti [Reasoning]. This helps in the fulfillment of the human life that is Dharma (virtue), Artha (wealth) and Kama (desire). ${ }^{[46]}$

Yukti (Reasoning) is valuable source of knowledge and because of its utilization value in the world, it is one of the convincing methods advocated by the ancient Ayurvedic experts. It has been treated as a source of knowledge in the present context.[47] It is basically a conclusion drawn on the basis of Past, Present and Future. It is a multidimensional aspect which helps to understand the different concepts logically.[48] Importance of Yukti Pramana cannot be overlooked during Ayurvedic research, as per Acharya Charak there remain no drug which is not medicine if there is Yukti.[49]

In Ayurveda, application of experimental method (Yukti Pramana) can be done in the following areas: 
Int. J. Ayur. Pharma Research, 2020;8(11):36-46

1. Dose and time schedule of drug.

2. Methods of analysis.

3. Synthesis and compounding.

4. Isolation of particular extract.

5. Application of a drug or its fraction in a modified form.

6. Application of a drug with various vehicles (Anupana). 'Anupana is a substance administered with the medicine to increase its potency, absorption, mode of action etc.'[50]

For example: Triphala can be given alone for reducing obesity, but Triphala with honey/warm water can help reducing obesity more quickly. This hypothesis, can be made on the basis of Yukti Pramana, and the same drug when used with Ghrita and honey it reduces eye complaints, which means one drug can be used in various diseases with different aspects with the help of Yukti. Thus, it proves while conducting drug research Yukti Pramana is used.[51]

\section{Prashna and Sambhasha}

In another method of investigation or examination comes the Prashna Pariksha [The method of Interrogation]. In Ayurveda, according to Acharya Charak there are three methods used in Rogi Pariksha they are Darshan, Sparshan, Prashna (Interrogation). The two Darshan and Sparshan methods are to evaluate the condition of patient and in the conditions of fever, edema etc evaluate the patient by touching. [52]

The interrogation method plays an important role besides the two mentioned above, as it gives the precise knowledge along with proper and detailed history of a patient which helps in proper diagnosis.

The information collected by the interrogation is very helpful for interpretation and correlation of observed facts while taking history. This process is useful in any type of research like, Drug research for a particular disease, experiment of drug over group of patients, etc.

Sambhasha means discussion. Acharya Charak and many of the ancient experts have recommended this classical method for the establishment of facts, acceptance of new fact. In the Ayurvedic field of research, discussion with specialist physicians promote the pursuit and upgradation, advancement of knowledge, improves the power of speaking, gives fame, avoid repetitions about some topic and clear the doubts about philosophy and in scriptures of that particular topic, generates new concepts or ideas and increase confidence about the matter.[53]

\section{Other Methods of Observations}

Besides, the broad classification of principles for basic research knowledge in Ayurveda, Acharyas have also quoted many more important factors to be considered during research such as; Dosha Avastha and Bheshaja Avastha in human body.[54] The differences in variations of Dosha, medicinal drugs, location, time, strength, body, diet, wholesomeness, mind, constitution and age is very subtle. Such subtilities baffle the intelligence, even of the exceedingly brilliant persons who have clean understanding of the subject. ${ }^{[55]}$ All these factors help to attain Vyadhi moksha, which is the basic requirement of Ayurvedic research.

\section{Panchaavayava[56]}

Co-relation of Panchaavayava with modern research tools:

\begin{tabular}{|l|l|l|l|}
\hline & $\begin{array}{l}\text { Traditional } \\
\text { Terminology }\end{array}$ & Modern tools and Technique & \multicolumn{1}{|c|}{ Practical aspects } \\
\hline 1. & Pratigya & Hypothesis or title of thesis & $\begin{array}{l}\text { Loha Bhasma is effective in iron deficiency } \\
\text { anemia. }\end{array}$ \\
\hline 2. & Hetu & $\begin{array}{l}\text { Research method, techniques, } \\
\text { lab tools, protocol }\end{array}$ & $\begin{array}{l}\text { We will get the information about Loha Bhasma } \\
\text { qualities through literatures, articles, } \\
\text { Aptopadesha, Pratyaksha, Anumana, Yukti. }\end{array}$ \\
\hline 3. & Udaharan & $\begin{array}{l}\text { Previous research work, thesis } \\
\text { on same topic }\end{array}$ & $\begin{array}{l}\text { Food products rich in Iron content will increase } \\
\text { haemoglobin and corrects anemia. }\end{array}$ \\
\hline 4. & Upanay & $\begin{array}{l}\text { The conclusion, discussion part } \\
\text { of a research work }\end{array}$ & $\begin{array}{l}\text { Similarly, Loha Bhasma acts in our body to fight } \\
\text { anemia. }\end{array}$ \\
\hline 5. & Nigaman & Revalidation of the hypothesis & $\begin{array}{l}\text { So, it is concluded that Loha Bhasma is Effective } \\
\text { in Iron Deficiency Anemia. }\end{array}$ \\
\hline
\end{tabular}


Samkhya ${ }^{[57]}$

In Ayurveda the detailed description of Doshas, Dhatus, Malas etc. are concise in numerical form/ science which give a statistical knowledge.

These figures help in comparison of constituents according to different Acharyas and detailed description helps in the decision of management.

The statistics helps in comparison and drawing a definite and precise conclusion.

\section{Research Tools- Tantrayukti, Tantra ${ }^{[58]}$}

In Ayurvedic literary researches, various tools were used for study such as- Tantrayukti (techniques of exposition) which is generally defined as the technical terminology, methodology or technique which enables a person to interpret scientific treaties in a proper and intelligent manner. ${ }^{[59]}$ Systemic and scientific approach to a Shastra for easy understanding of that particular Shastra is also called Tantrayukti. In literary research, these Tantrayukti are important as:[60]

1. For elaborating the exact statements given in the texts.

2. For exploring or searching hidden meanings of the textual statements, with the help of Arthayojna Tantrayukti.

3. To correct and rearrange irrelevant sentences in the texts, with the help of Vakyayojna Tantrayukti.

A researcher can reestablish a new fact in literary research with the help of various Tantryuktis.

\section{Pratisanskar}

In Ancient time, the traditional method of gaining knowledge was through teaching and studying in Gurukuls, Ashrams etc which gives the concept of institutes and universities where a scholar must learn the basics of literature. Ancient Ayurvedic had this unique quality of super natural sense or intuition which helped them to acquire the knowledge of the universe, nature, medicinal plant, elements of body etc. Origin of Ayurveda as per Charak Samhita was first from Agnivesha tantra written by Agnivesha the student of Punarvasu Atreya from whom they acquire the knowledge of Ayurveda. Later on, the modification of the Samhita done by Acharya Charak and then by Acharya Dridabala who completed the Charak Samhita by adding 41 chapters in it. This shows that re-editing the old literature with the addition of new advanced knowledge and remolding of doubtful unwanted facts. Thus, one has to understand the protocol of research applied by the ancient Ayurvedic experts. The same should be applied along with modern research protocol.[61]
Research is a systematic activity which is directed towards the discovery and development of an organized knowledge. It is a stepwise study where every step has its significance. As per Ayurvedic perspective the methods of observation, examination, investigations, discussion and interrogations etc. are to prove Ayurvedic principles from a modern point of view.

All these methods give the knowledge to understand the principles and untoward phenomenon of Ayurvedic science. The Pramanagyana helps to understand the cause and effect relationship for proper understanding of Ayurvedic concepts. Interrogation helps to understand the current problems and to find out the solutions. To attain the Vyadhi moksha state detailed knowledge of Dosha Avastha, Panchaavayava, Samkhya, Tantrayukti are very important. All these tools help us in advancement of research methodology with the help of the ancient literature and methods.

\section{CONCLUSION}

In ancient times the treatments told by Acharyas are timely tested. Many references told in Ayurvedic Samhitas are evidence to modern research methodology. Ayurvedic research will fulfill our expectations only when it is one according to the guidelines quoted in the Samhitas. A standard protocol inclusive of all the above factors needs to be prepared to give a sturdy base for Ayurvedic research.

\section{REFERENCES}

1. Dr.Subhash Ranade, Dr.R.R.Deshpande. Author Dr.Sachin Sarpotdar, Dr.Santosh Bhor and Dr.Ila. Bhor Research Methodology and Medical Statistics $5^{\text {th }}$ edition, published by Girish D. Gandhi Manikarnika publication, Pune. P.N. 64-67

2. Research, Wikipedia, Merriam-Webster.com. Merriam-Webster, Inc. Retrieved 20 May 2018. Available from https://en.wikipedia.org/wiki/ Research.

3. Dr.Subhash Ranade, Dr.R.R.Deshpande. Author Dr.Sachin Sarpotdar, Dr.Santosh Bhor and Dr.Ila. Bhor Research Methodology and Medical Statistics $5^{\text {th }}$ edition, published by Girish D. Gandhi Manikarnika publication, Pune. P.N. 15.

4. Santosh N. Belavadi: Understanding Research Methodology under Ayurvedic Parlance. ayurpub 2017; II (2):370.

5. Dr.Subhash Ranade, Dr.R.R.Deshpande. Author Dr.Sachin Sarpotdar, Dr. Santosh Bhor and Dr.Ila. Bhor Research Methodology and Medical Statistics $5^{\text {th }}$ edition, published by Girish D. Gandhi Manikarnika publication, Pune. P.N. 19. 
6. Kashinath Shastri, Vaidya Yadavaji Trikamaji Acharya, Agnivesha Charak Samhita Chakrapani Datta Virachita Ayurveda Dipika Vyakhyana Hindi Sutra Sthana Chapter 9/121, $4^{\text {th }}$ edition Chaukhamba Sanskrit Sansthan, Varanasi, 1994, P.N. 137.

7. Dr.Subhash Ranade, Dr.R.R.Deshpande. Author Dr.Sachin Sarpotdar, Dr. Santosh Bhor and Dr.Ila. Bhor Research Methodology and Medical Statistics $5^{\text {th }}$ edition, published by Girish D. Gandhi Manikarnika publication, Pune. P.N. 1920.

8. Santosh N. Belavadi: Understanding Research Methodology under Ayurvedic Parlance. ayurpub 2017; II (2):371.

9. Dr.Dyaneshwar K. Jadav, Manual of Research Methodology and Medical Statistics, published by Chaukhambha Subharati Prakashan, First edition 2017, P.N. 3-4.

10. Pt.Kashinath Shastri, Dr. Gorakhanath Chaturvedi, Charak Samhita, with Vidyotini Hindi Commentary, Sutra Sthana Chapter 1/124, published by Chaukhambha Bharati Academy 2015, P.N. 48

11. Pt.Kashinath Shastri, Dr. Gorakhanath Chaturvedi, Charak Samhita, with Vidyotini Hindi Commentary, Sharir Sthana Chapter 5/3, published by Chaukhamba Bharati Academy 2015, P.N. 886

12. Dr.K.V.L.Narasimhacharyulu, Padartha Vigyana $4^{\text {th }}$ edition 2010, published by Chaukhamba Krishnadas Academy, Varanasi P.N. 188.

13. Dr.K.V.L.Narasimhacharyulu, Padartha Vigyana $4^{\text {th }}$ edition 2010, published by Chaukhamba Krishnadas Academy, Varanasi P.N. 204.

14. Pt.Kashinath Shastri, Dr. Gorakhanath Chaturvedi, Charak Samhita, with Vidyotini Hindi Commentary, Vimana Sthana Chapter 4/3, published by Chaukhamba Bharati Academy 2015, P.N. 702.

15. Pt.Kashinath Shastri, Dr.Gorakhanath Chaturvedi, Charak Samhita, with Vidyotini Hindi Commentary, Sutra Sthana Chapter 11/17, published by Chaukhamba Bharati Academy 2015, P.N. 215.

16. Dr.Yogesh Chandra Mishra, Basic Principles of Ayurveda Padartha Vigyana, edition reprint 2007, published by Chaukhamba Sanskrit Sansthan, Varanasi P.N. 348.

17. Pt.Kashinath Shastri, Dr. Gorakhanath Chaturvedi, Charak Samhita, with Vidyotini Hindi Commentary, Vimana Sthana Chapter 8/39, published by Chaukhamba Bharati Academy 2015, P.N. 753.
18. Pt.Kashinath Shastri, Dr.Gorakhanath Chaturvedi, Charak Samhita, with Vidyotini Hindi Commentary, Sutra Sthana Chapter 11/20, published by Chaukhamba Bharati Academy 2015, P.N. 217

19. Pt.Kashinath Shastri, Dr. Gorakhanath Chaturvedi, Charak Samhita, with Vidyotini Hindi Commentary, Sharir Sthana Chapter 1/54, published by Chaukhamba Bharati Academy 2015, P.N. 714.

20. Dr.K.V.L.Narasimhacharyulu, Padartha Vigyana $4^{\text {th }}$ edition 2010, published by Chaukhamba Krishnadas Academy, Varanasi P.N. 217.

21. Pt.Kashinath Shastri, Dr.Gorakhanath Chaturvedi, Charak Samhita, with Vidyotini Hindi Commentary, Sharir Sthana Chapter 1/48, published by Chaukhamba Bharati Academy 2015, P.N. 19

22. Dr.K.V.L. Narasimhacharyulu, Padartha Vigyana $4^{\text {th }}$ edition 2010, published by Chaukhamba Krishnadas Academy, Varanasi P.N. 219

23. Pt.Kashinath Shastri, Dr.Gorakhanath Chaturvedi, Charak Samhita, with Vidyotini Hindi Commentary, Sharir Sthana Chapter 8/8-12, published by Chaukhamba Bharati Academy 2015, P.N. 176.

24. Dr.K.V.L.Narasimhacharyulu, Padartha Vigyana $4^{\text {th }}$ edition 2010, published by Chaukhamba Krishnadas Academy, Varanasi P.N. 260-262.

25. Dr.K.V.L.Narasimhacharyulu, Padartha Vigyana $4^{\text {th }}$ edition 2010, published by Chaukhamba Krishnadas Academy, Varanasi P.N. 97.

26. Pt.Kashinath Shastri, Dr. Gorakhanath Chaturvedi, Charak Samhita, with Vidyotini Hindi Commentary, Sharir Sthana Chapter 1/18-19, published by Chaukhamba Bharati Academy 2015, P.N. 703-704.

27. Pt.Kashinath Shastri, Dr. Gorakhanath Chaturvedi, Charak Samhita, with Vidyotini Hindi Commentary, Sutra Sthana Chapter 8/7, published by Chaukhamba Bharati Academy 2015, P.N. 176.

28. Dr.Ambika Datta Shastri, Sushruta Samhita, Purvardha with Ayurvedatatvasandipika Hindi Commentary, Sutra Sthana 15/48, Chaukhamba Sanskrit Sansthan, Varanasi. 84.

29. Dr.Yogesh Chandra Mishra, Basic Principles of Ayurveda Padartha Vigyana, edition reprint 2007, published by Chaukhamba Sanskrit Sansthan, Varanasi P.N. 194.

30. Pt.Kashinath Shastri, Dr. Gorakhanath Chaturvedi, Charak Samhita, with Vidyotini Hindi Commentary, Sharir Sthana Chapter 1/98, 
Kirti Soni, Rohit Ranjan, Vijay Shankar Pandey. Ancient Methods of Research In Ayurveda

published by Chaukhamba Bharati Academy 2015, P.N. 823

31. Pt.Kashinath Shastri, Dr. Gorakhanath Chaturvedi, Charak Samhita, with Vidyotini Hindi Commentary, Sutra Sthana Chapter 11/43, published by Chaukhamba Bharati Academy 2015, P.N. 233

32. Dr.Yogesh Chandra Mishra, Basic Principles of Ayurveda Padartha Vigyana, edition reprint 2007, published by Chaukhamba Sanskrit Sansthan, Varanasi P.N. 395

33. Dr.Yogesh Chandra Mishra, Basic Principles of Ayurveda Padartha Vigyana, edition reprint 2007, published by Chaukhamba Sanskrit Sansthan, Varanasi P.N. 395

34. Pt.Kashinath Shastri, Dr. Gorakhanath Chaturvedi, Charak Samhita, with Vidyotini Hindi Commentary, Vimana Sthana Chapter 8/40, published by Chaukhamba Bharati Academy 2015, P.N. 753

35. Pt.Kashinath Shastri, Dr. Gorakhanath Chaturvedi, Charak Samhita, with Vidyotini Hindi Commentary, Sutra Sthana Chapter 11/21-22, published by Chaukhamba Bharati Academy 2015, P.N. 219

36. Dr. K.V.L. Narasimhacharyulu, Padartha Vigyana $4^{\text {th }}$ edition 2010, published by Chaukhamba Krishnadas Academy, Varanasi P.N. 272.

37. Dr.Yogesh Chandra Mishra, Basic Principles of Ayurveda Padartha Vigyana, edition reprint 2007, published by Chaukhamba Sanskrit Sansthan, Varanasi P.N. 398.

38. Pt.Kashinath Shastri, Dr. Gorakhanath Chaturvedi, Charak Samhita, with Vidyotini Hindi Commentary, Vimana Sthana Chapter 4/8, published by Chaukhamba Bharati Academy 2015, P.N. 707.

39. Dr.K.V.L.Narasimhacharyulu, Padartha Vigyana $4^{\text {th }}$ edition 2010, published by Chaukhamba Krishnadas Academy, Varanasi P.N. 301.

40. Dr.Subhash Ranade, Dr.R.R.Deshpande. Author Dr.Sachin Sarpotdar, Dr. Santosh Bhor and Dr. Ila. Bhor Research Methodology and Medical Statistics $5^{\text {th }}$ edition, published by Girish D. Gandhi Manikarnika publication, Pune. P.N. 65.

41. Pt.Kashinath Shastri, Dr.Gorakhanath Chaturvedi, Charak Samhita, with Vidyotini Hindi Commentary, Vimana Sthana Chapter 4/3, published by Chaukhamba Bharati Academy 2015, P.N. 704.

42. Pt.Kashinath Shastri, Dr.Gorakhanath Chaturvedi, Charak Samhita, with Vidyotini Hindi Commentary, Sutra Sthana Chapter 11/18-19, published by Chaukhamba Bharati Academy 2015, P.N. 216

43. Dr.Yogesh Chandra Mishra, Basic Principles of Ayurveda Padartha Vigyana, edition reprint 2007, published by Chaukhamba Sanskrit Sansthan, Varanasi P.N. 428.

44. Dr.K.V.L.Narasimhacharyulu, Padartha Vigyana $4^{\text {th }}$ edition 2010, published by Chaukhamba Krishnadas Academy, Varanasi P.N. 303.

45. Vaman Shivram Apte, Dr. Uma Prasad Pandey, Sanskrit Hindi Shabdakosh, published by Kamal Prakashan, P.N. 898.

46. Pt.Kashinath Shastri, Dr. Gorakhanath Chaturvedi, Charak Samhita, with Vidyotini Hindi Commentary, Sutra Sthana Chapter 11/25, published by Chaukhamba Bharati Academy 2015, P.N. 221.

47. Dr.Sharma R.K., Vaidya B Dash, Charak Samhita, English translation \& critical exposition based on Chakrapani Datta's Ayurveda Dipika, Published by: Chaukhamba Sanskrit Series Office, Varanasi, Reprint Edition: 2012. Sutra Sthana 11/25.

48. Dr.Subhash Ranade, Dr.R.R.Deshpande. Author Dr.Sachin Sarpotdar, Dr.Santosh Bhor and Dr.Ila. Bhor Research Methodology and Medical Statistics $5^{\text {th }}$ edition, published by Girish D. Gandhi Manikarnika publication, Pune. P.N. 64

49. Pt.Kashinath Shastri, Dr.Gorakhanath Chaturvedi, Charak Samhita, with Vidyotini Hindi Commentary, Sutra Sthana Chapter 26/12, published by Chaukhamba Bharati Academy 2015, P.N. 492.

50. Dr.Subhash Ranade, Dr.R.R.Deshpande. Author Dr.Sachin Sarpotdar, Dr.Santosh Bhor and Dr.Ila. Bhor Research Methodology and Medical Statistics, published by Girish D.Gandhi Manikarnika publication, Pune. P.N. 134.

51. Dr.Subhash Ranade, Dr.R.R.Deshpande. Author Dr.Sachin Sarpotdar, Dr. Santosh Bhor and Dr. Ila. Bhor Research Methodology and Medical Statistics $5^{\text {th }}$ edition, published by Girish D. Gandhi Manikarnika publication, Pune. P.N. 65.

52. Pt.Kashinath Shastri, Dr.Gorakhanath Chaturvedi, Charak Samhita, with Vidyotini Hindi Commentary, Sutra Sthana Chapter 8/83, published by Chaukhamba Bharati Academy 2015, P.N. 767.

53. Dr.Subhash Ranade, Dr.R.R.Deshpande. Author Dr.Sachin Sarpotdar, Dr. Santosh Bhor and Dr. Ila. Bhor Research Methodology and Medical Statistics $5^{\text {th }}$ edition, published by Girish D. Gandhi Manikarnika publication, Pune. P.N. 75.

54. Dr.Subhash Ranade, Dr. R. R. Deshpande. Author Dr.Sachin Sarpotdar, Dr. Santosh Bhor and Dr. Ila. 
Bhor Research Methodology and Medical Statistics $5^{\text {th }}$ edition, published by Girish D. Gandhi Manikarnika publication, Pune. P.N. 69.

55. Dr.Sharma R.K., Vaidya B Dash, Charak Samhita, English translation, published by Chaukhamba Krishnadas Academy, Varanasi. Sutra Sthana 15/5.

56. Dr. Suparna Saha, role of Panchaavayava vakya in Ayurvedic literature; in the perspective of research, IJAHM 2017 P.N. 2917.

57. Dr.Subhash Ranade, Dr.R.R.Deshpande. Author Dr.Sachin Sarpotdar, Dr.Santosh Bhor and Dr.Ila. Bhor Research Methodology and Medical Statistics, published by Girish D. Gandhi Manikarnika publication, Pune. P.N. 135.

58. Dr.Subhash Ranade, Dr.R.R.Deshpande. Author Dr.Sachin Sarpotdar, Dr.Santosh Bhor and Dr.Ila.
Bhor Research Methodology and Medical Statistics $5^{\text {th }}$ edition, published by Girish D. Gandhi Manikarnika publication, Pune. P.N. 136.

59. Dr.K.V.L.Narasimhacharyulu, Padartha Vigyana $4^{\text {th }}$ edition 2010 , published by Chaukhamba Krishnadas Academy, Varanasi P.N. 433.

60. Dr.Subhash Ranade, Dr.R.R.Deshpande. Author Dr.Sachin Sarpotdar, Dr.Santosh Bhor and Dr.Ila. Bhor Research Methodology and Medical Statistics $5^{\text {th }}$ edition, published by Girish D. Gandhi Manikarnika publication, Pune. P.N. 76.

61. Dr.Subhash Ranade, Dr.R.R.Deshpande. Author Dr.Sachin Sarpotdar, Dr.Santosh Bhor and Dr.Ila. Bhor Research Methodology and Medical Statistics $5^{\text {th }}$ edition, published by Girish D. Gandhi Manikarnika publication, Pune. P.N. 136.

\section{Cite this article as:}

Kirti Soni, Rohit Ranjan, Vijay Shankar Pandey. Ancient Methods of Research In Ayurveda. International Journal of Ayurveda and Pharma Research. 2020;8(11):36-46.

Source of support: Nil, Conflict of interest: None Declared

\section{*Address for correspondence Dr. Kirti Soni \\ MD Scholar \\ Department of Ayurved Samhita and \\ Siddhanta, \\ Government Ayurvedic College, \\ Patna, Bihar. \\ Email: drsonikirti@gmail.com}

Disclaimer: IJAPR is solely owned by Mahadev Publications - dedicated to publish quality research, while every effort has been taken to verify the accuracy of the content published in our Journal. IJAPR cannot accept any responsibility or liability for the articles content which are published. The views expressed in articles by our contributing authors are not necessarily those of IJAPR editor or editorial board members. 